\title{
Characteristics of electricity quality parameters in agri-food processing plants
}

\author{
Krzysztof Necka ${ }^{l, *}$, Matgorzata Trojanowska ${ }^{1}$ \\ ${ }^{1}$ Faculty of Production and Power Engineering, University of Agriculture in Krakow, Poland,
}

\begin{abstract}
The paper presents the results of electricity quality measurements conducted in six agri-food processing plants equipped with receivers of different sensitivity to the quality of the supply voltage. In particular, statistical assessment has been conducted for the value of the parameters characterizing the supply voltage, describing the parameters using the basic statistical measures and comparing them with the normative requirements. The paper also presents examples of the hazards to electrical drives and control systems caused by such industrial electromagnetic interferences as voltage changes or deformations of voltage waveform.
\end{abstract}

\section{Introduction}

At present, electricity is the basic energy medium necessary for the efficient functioning of most economic entities, especially industrial plants, including agri-food processing plants. Currently, there are approximately a dozen or so thousands of such entities in Poland with different production scales and forms of ownership.

The way in which power is supplied in food processing plants is extremely important. The choice of power supply is mainly determined by the supply reliability. It depends on the amount of losses in the event of a power failure. The amount of losses is estimated at 30-150 times the cost of electricity not supplied $[1,2]$. The losses may be even greater in the case of freezing or meat plants.

Additional costs of plants are generated not only due to unplanned downtime associated with interruptions in power supply, but also due to improper operation of equipment resulting from the poor quality of electricity, which causes abnormalities in the manufacturing process and also faster wear and tear or even damagesof electrical equipment [3-7].Electricity consumers are not fully aware that the poor quality of electricity can be the reason for the additional production costs associated with malfunctioning equipment. It can help the plant in gaining competitive advantage by reducing production costs to conduct continuous monitoring or at least periodic energy quality measurements [8-11].

\section{Purpose, scope and subject matter of the study}

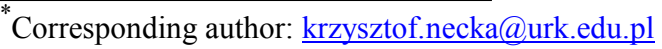

The aim of the study was to analyze the quality of electricity in six selected agri-food processing plants. The

study included two water bottling plants (hereinafter referred to in the paper as plants R1 and R2), three meat plants (plants M1, M2, M3) and one bakery (plant P). Each of the plants is modernly equipped and powered by its own transformer/distribution station 15/0.4 kV. Most of the electrical systems used in them are adjustable electric drives. The paper presents examples of threats caused by electromagnetic disturbances to the electric drives and related control systems.

\section{Study method}

The quality of electricity is the same as the quality of the supply voltage and includes two groups of disturbances:

- changes, i.e. small deviations from the nominal or desired magnitude, including free voltage changes, voltage fluctuations, asymmetry and higher harmonics of voltages,

- events, i.e. sudden and significant deviations from the nominal or desired magnitude, including rapid voltage changes, voltage dips, voltage increases and transient overvoltages, short power interruptions.

The AS-3 Plus portable parameter analyzer, along with current transformers, was used to test the quality of electrical power in the plants, allowing for both, the detection of changes and the recording of events related to the values of voltage parameters describing its quality. The measurements were made each time at the main switchrooms of the plants, at the points of electricity supply. In particular, the phase and phase-to-phase 
voltages, voltage asymmetry, the content of higher harmonics and the THD factor for voltages and currents as well asexceedances of the set tolerances of the measured parameters, voltage dips and increases, etc. were continuously monitored.

\section{Results}

Electricity quality is defined as a set of parameters describing the characteristics of the energy supply process under normal operating conditions [12]. Both the supplier and the customer are responsible for electricity quality. Suppliers, by virtue of the power grid service, are mainly responsible for the supply voltage. Consumers, in turn, are responsible for the quality of the current, affecting its course through the operation of electrical equipment, which can impair the voltage parameters.

The studied agri-food processing plants are equipped with a large number of modern adjustable electric drives. Such electric drive consists of:

- electric motor driving a work machine with adjustable parameters (usually rotational speed or torque),

- a system for converting electrical energy with fixed parameters into electrical energy with variable parameters, resulting from the technological process needs (usually energy-electronic converter),

- a system controlling processing device.

The control is implemented by microprocessor circuits and programmable PLC logic controllers. The whole is complemented by contactors and relays used to connect or disconnect both power and control circuits. All these components are very sensitive to the voltage quality, but not equally sensitive to each of its parameters. The nuisance of the supply voltage disturbances can be ranked in the following order: voltage dips, short power interruptions, voltage values, higher harmonics, overvoltages, asymmetry, fluctuations and voltage frequency $[3,4]$.

Supply voltage dip is a sudden decrease in the effective voltage to a value in the range of $90 \%$ and $5 \%$ of the rated voltage [13], followed by a voltage increase to the previous value in a short period of time (usually 10 $\mathrm{ms}-1 \mathrm{~min}$ ). A specific form of the voltage dip is short power interruption. It is recorded when the voltage goes down below $5 \%$ of the nominal value. According to the Minister Regulation [12], short power interruptions last longer than 1 second and no longer than 3 minutes.

The regulations in force in Poland do not specify the requirements for voltage dips and short power interruptions. By contrast, according to PN-EN 50160 [13], voltage dips can be recorded from several dozen to one thousand times a year, while the number of short power interruptions ranges from several dozens to several hundred.

In the studied agri-food industry plants, the problem of voltage dips and short power interruptions occurred with varying intensity (Table 1). The largest number of voltage dips, in the number of about 10 thousand annually, was recorded in the bakery, but the number of dips was also too high, as compared to the requirements of the standard, in all of the studied meat plants. The registered dips were, however, characterized by small depths (an average of $10-12 \%$ of the rated voltage) and short duration (an average of approx. 1 second). Short voltage supply interruptions were problematic in none of the plants.

Table 1. Characteristics of voltage dips and short power interruptions.

\begin{tabular}{|c|c|c|c|c|c|}
\hline$\frac{\vec{\Xi}}{\underline{E}}$ & 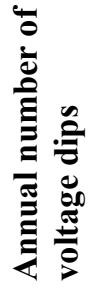 & 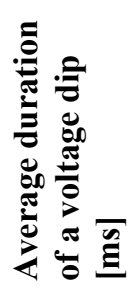 & 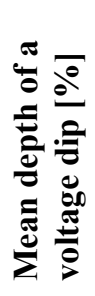 & 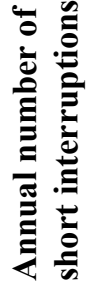 & 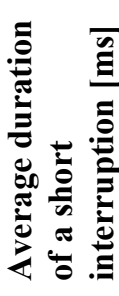 \\
\hline $\mathrm{R} 1$ & 114 & 427 & 19 & 4 & 2550 \\
\hline R2 & 126 & 355 & 19 & 0 & 0 \\
\hline M1 & 6811 & 1124 & 10 & 8 & 4810 \\
\hline M2 & 7855 & 1244 & 10 & 58 & 3562 \\
\hline M3 & 2815 & 1226 & 11 & 4 & 1600 \\
\hline $\mathrm{P}$ & 9857 & 804 & 12 & 0 & 0 \\
\hline
\end{tabular}

Microprocessor circuits are exceptionally sensitive to voltage dips and short power interruptions, and the most common effects include: no data transmission or errors in their transmission.

The inadequate voltage supply that is sustained on the receivers' terminals for a long time is another cause of disturbances in the operation of agro-food industry plants. According to the regulations in force in Poland, $95 \%$ of a set of 10-minute average voltage effective values at the point of supply of electricity from a low voltage network shall be within $\pm 10 \%$ of the rated voltage [12]. Exceeding the limit values adversely affects the operation of propulsion engines, resulting in changes in their torque and rotational speed, disrupting their microprocessor systems used to control the motors, as well as the contactors and relays used as connecting elements. The analysis of the voltage measurements in all of the studied plants allowed us to conclude that, in terms of the supply voltage, the normative requirements were fulfilled.

Such a statement could not be tolerated with respect to another, potentially harmful, electromagnetic disturbance which is voltage distortion [14-15]. According to therequirements in force in Poland [12, 13], its evaluation is based on the following criteria:

- the permissible values of individual higher harmonics,

- the permissible value of the Total Harmonic Distortion, $\mathrm{THD}_{\mathrm{U}}$.

The criteria must be fulfilled simultaneously, which in practice means that if one of the higher harmonics approaches the limit value, the remaining ones must be much smaller so that the total $\mathrm{THD}_{\mathrm{U}}$ factor value did not exceed the limit value of $8 \%$. 
Controlled drives, like most electrical systems, are susceptible to such disturbances as disorted voltage. Higher harmonics in the supply voltage cause, among others, worse operating conditions of the insulation due to increased working temperature, which results in a shorter operating life. With a lot of disturbances of this type, interference can also be recorded in the operation of control and protection devices, caused by the increase of the peak current and voltage.

The analyzes performed (Tables 2 and 3) show that the supply voltage of the studied plants most frequently exceeded the permissible levels of the 5th, 6th, 7 th and 15th harmonics, but the facilities differed in the intensity of the exceedances of the limit values for particular harmonics due to different characteristics of the equipment used. However, the number of the events was very low for most of the plants studied.

Table 2. Breakdown of the permissible levels of individual higher harmonics in the supply voltage.

\begin{tabular}{|c|c|c|c|c|c|c|c|}
\hline \multicolumn{2}{|c|}{ Plant } & R1 & R2 & M1 & M2 & M3 & $\mathbf{P}$ \\
\hline \multirow{12}{*}{ 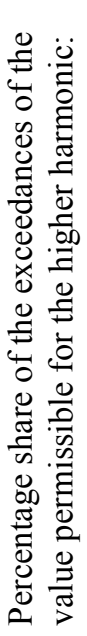 } & 2 & 18.0 & 0.0 & 0.0 & 0.0 & 0.0 & 0.0 \\
\hline & 4 & 9.0 & 0.0 & 0.0 & 0.0 & 0.0 & 0.0 \\
\hline & 5 & 0.0 & 0.0 & 0.0 & 0.0 & 0.7 & 48.0 \\
\hline & 6 & 27.0 & 100.0 & 0.0 & 0.0 & 0.0 & 0.0 \\
\hline & 7 & 0.0 & 0.0 & 0.0 & 0.0 & 56.7 & 0.0 \\
\hline & 8 & 9.0 & 0.0 & 0.0 & 0.0 & 0.0 & 0.0 \\
\hline & 10 & 9.0 & 0.0 & 0.0 & 0.0 & 0.0 & 0.0 \\
\hline & 11 & 0.0 & 0.0 & 0.0 & 0.0 & 0.4 & 3.7 \\
\hline & 12 & 9.0 & 0.0 & 0.0 & 0.0 & 0.1 & 0.0 \\
\hline & 13 & 0.0 & 0.0 & 0.0 & 0.0 & 3.5 & 0.0 \\
\hline & 14 & 9.0 & 0.0 & 0.0 & 0.0 & 0.1 & 0.0 \\
\hline & 15 & 9.0 & 0.0 & 0.0 & 0.0 & 38.5 & 48.1 \\
\hline
\end{tabular}

The M3 meat plant was the exception, the daily average number of such disturbances was close to 9 . During the exceedances of the permissible levels for single harmonics, the $\mathrm{THD}_{U}$ value in plants $\mathrm{R} 1$ and $\mathrm{P}$ exceeded the permissible level of $8 \%$, and it was close to it for the M3 plant.

Throughout the entire measurement period, the $\mathrm{THD}_{U}$ limit was exceeded in the same plant, but the annual number of the exceedances was at a very different level of 4 to 112 events, respectively. There were also disturbing situations in the M2 and M3 plants, where the $\mathrm{THD}_{\mathrm{U}}$ value was close to the limit values.

The current course has a decisive influence on the distortion of the supply voltage waveform. During the assessment of the current course, distortion of higher harmonics, the content of individual harmonics was verified in accordance with the requirements of the Transmission Network Code[16].

The analyzes show (Table 4) that exceedances of the permissible distortion levels for the current course were recorded in two of the studied plants and mostly concerned the 3rd, 5th, 11th and 13th harmonics, with a significant number, between 4 and 10 per day.

Table 3. Characteristics of the Total Harmonic Distortion, $\mathrm{THD}_{\mathrm{U}}$.

\begin{tabular}{|c|c|c|c|c|c|c|c|}
\hline \multicolumn{2}{|c|}{ Plant } & R1 & R2 & M1 & M2 & M3 & $\mathbf{P}$ \\
\hline \multicolumn{2}{|c|}{ 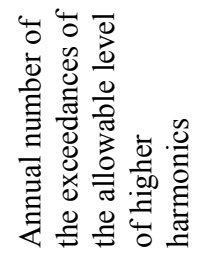 } & 12 & 9 & 0 & 0 & 3240 & 30 \\
\hline \multirow{4}{*}{ 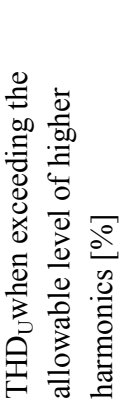 } & ·灵 & 2.70 & 2.10 & 0.00 & 0.00 & 2.70 & 6.20 \\
\hline & $\begin{array}{l}000 \\
\vec{\Xi}\end{array}$ & 5.43 & 2.17 & 0.00 & 0.00 & 3.90 & 7.50 \\
\hline & 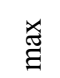 & 9.80 & 2.30 & 0.00 & 0.00 & 7.90 & 9.70 \\
\hline & $\theta$ & 0.52 & 0.12 & 0.00 & 0.00 & 0.71 & 1.13 \\
\hline \multirow{4}{*}{ 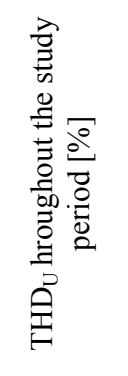 } & .尹 & 0.50 & 0.50 & 0.00 & 0.00 & 0.00 & 0.00 \\
\hline & $\begin{array}{l}000 \\
\gtrsim \\
\gtrsim\end{array}$ & 1.23 & 1.26 & 1.82 & 2.66 & 2.72 & 3.45 \\
\hline & $\begin{array}{l}\stackrel{x}{\Xi} \\
\text { J }\end{array}$ & 9.80 & 2.80 & 3.06 & 6.73 & 7.96 & 9.99 \\
\hline & के & 0.96 & 0.24 & 0.36 & 0.73 & 0.82 & 1.16 \\
\hline \multicolumn{2}{|c|}{ 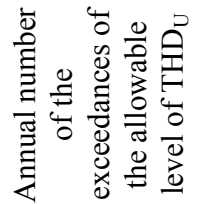 } & 4 & 0 & 0 & 0 & 0 & 112 \\
\hline
\end{tabular}


Table 4. Breakdown of the exceedances of the permissible levels of individual higher harmonics in current and the $\mathrm{THD}_{\mathrm{I}}$ levels.

\begin{tabular}{|c|c|c|c|c|c|c|c|}
\hline \multicolumn{2}{|c|}{ Plant } & R1 & $\mathbf{R 2}$ & M1 & M2 & M3 & $\mathbf{P}$ \\
\hline \multirow{7}{*}{ 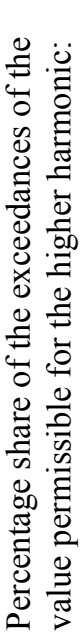 } & 3 & 0.0 & 84.0 & 0.0 & 0.4 & 0.0 & 0.0 \\
\hline & 5 & 0.0 & 72.0 & 0.0 & 41.4 & 0.0 & 0.0 \\
\hline & 7 & 0.0 & 0.0 & 0.0 & 0.8 & 0.0 & 0.0 \\
\hline & 9 & 0.0 & 0.0 & 0.0 & 0.4 & 0.0 & 0.0 \\
\hline & 11 & 0.0 & 0.0 & 0.0 & 28.2 & 0.0 & 0.0 \\
\hline & 13 & 0.0 & 0.0 & 0.0 & 19.5 & 0.0 & 0.0 \\
\hline & 15 & 0.0 & 0.0 & 0.0 & 9.2 & 0.0 & 0.0 \\
\hline \multirow{4}{*}{ 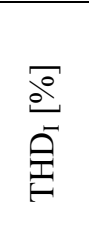 } & $\min$ & 0.0 & 5.0 & 0.0 & 7.1 & 0.0 & 0.0 \\
\hline & avg & 0.0 & 10.0 & 0.0 & 17.2 & 0.0 & 0.0 \\
\hline & $\max$ & 0.0 & 20.4 & 0.0 & 47.7 & 0.0 & 0.0 \\
\hline & SD & 0.0 & 3.2 & 0.0 & 4.9 & 0.0 & 0.0 \\
\hline \multicolumn{2}{|c|}{ 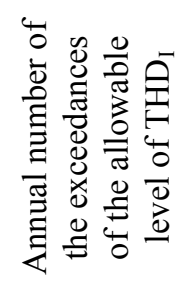 } & 0 & 1389 & 0 & 3739 & 0 & 0 \\
\hline
\end{tabular}

\section{Summary}

The results of the research on the quality of electricity in agri-food processing plants were analyzed. Measurements were made at the points of energy supply, as these are the only points for which regulations specify the requirements for the quality parameters of the supply voltage.

Each of the plants studied recorded less or more incidents of unsatisfactory voltage quality, especially with respect to the content of higher harmonics. Four of the studied plants recorded values of the $\mathrm{THD}_{\mathrm{U}}$ factor that were higher or close to the value allowed by regulations.

The repercussion of the distortion of the supply voltage waveform, as well as the majority of electromagnetic disturbances analyzed in the work, is among others the incrise of flowing current, with all the consequences.

Improving the quality of electricity is only possible after diagnosing and defining the causes of its deterioration. For this purpose, measurements of voltage quality parameters are required not only in the main switchrooms but also in local switchrooms, directly supplying equipment. The quality of electricity at the point of the connection of the plant to the grid is not the same as the quality of the power supply for the receivers themselves.

\section{Acknowledgements}

This research was financed by the Ministry of Science and Higher Education of the Republic of Poland

\section{Bibliography}

1. Problemy zaopatrzenia $\mathrm{w}$ energie $\mathrm{w}$ gospodarstwach rolnych oraz przemyśle rolno- spożywczym. Instytut Energetyki Odnawialnej.http://ieo.pl/en aktualności /1095-problemy-zaopatrzenia-w-energie - w gospodarstwach-rolnych - oraz - przemysle - rolnospozywczym

2. Hanzelka, Z., Automatyka, Elektryka, Zakłócenia, Vol. 3, Nr 7, s. 11-19, (2012)

3. Z. Hanzelka, A. Firlit, IV Konferencja Wytwórców Energii Elektrycznej i Cieplnej. Skawina 2527.09.2013(2013)

4. Jiansheng H. Zhuhan J. Energy Procedia. Volume 141 , s. $345-351$ doi.org/10.1016/j.egypro.2017.11.041 (2017)

5. H. Markiewicz, A. Klajn, Wydawnictwo Polskiego Centrum Promocji Miedzi nr 02/03, s. 3-20 (2003)

6. K. Strzałka-Gołuszka, J. Strzałka, Biuletyn SEP Kraków, nr 182-183, s. 39-65 (2010)

7. M. Wardach, A. Kiryluk, P. Cierzniewski, T. Zarębski, VIII Lubuska Konferencja NaukowoTechniczna - i-MITEL 2014 (2014)

8. Z. Hanzelka, II Ogólnopolska Konferencja „Elektroenergetyka na terenach wiejskich”, s. 22-28 (2004)

9. E. Musiał, Konferencja Automatyka, Pomiary, Zakłócenia. INFOTECH 2004, Jurata, 20-22 maja 2004 r., s. 103-122 (2004)

10. A. Pawlęga, Przegląd Elektrotechniczny nr 11, s. 805-810 (2003)

11. M. Trojanowska, K. Nęcka, Inżynieria Rolnicza nr 7(95), s. 221-227 (2007)

12. Rozporządzenie Ministra Gospodarki z dnia 4 maja 2007 w sprawie szczegółowych warunków funkcjonowania systemu energetycznego. Dz. U. nr 93 poz. 623 , z późniejszymi zmianami.

13. PN-EN 50160. 2010: Parametry napięcia zasilającego w publicznych sieciach rozdzielczych.

14. M. Jasiński, D. Kaczorowska, L. Jasińska, Ł. Jasiński, Zeszyty Naukowe Uczelni Jana 
Wyżykowskiego. Studia z Nauk Technicznych, 5, s. 127-134 (2016)

15. M. Olesz, Zeszyty Naukowe Wydziału Elektrotechniki i Automatyki Politechniki Gdańskiej Nr 50, s. 71-74, (2016)

16. Instrukcja ruchu i eksploatacji sieci dystrybucyjnej (zatwierdzona przez Prezesa URE decyzją nr DRR4321-60(5)/2013/KSm). Tauron Dystrybucja (2017) 